\title{
Developing Therapies with Functional Beta Cells to Treat Diabetes
}

\author{
Yicheng Zhao \\ College of life science, Northeast Forestry University, Harbin, China \\ E-mail: yichengzhao@live.cn
}

Received 3 September 2015; Accepted 24 September 2015; Publication 5 November 2015

\begin{abstract}
As the key regulator in maintaining blood sugar, insulin is secreted by beta cells residing in pancreatic islets. However, most functional beta cells are disappeared in type I diabetes, and the total beta cell population is seriously reduced in type II diabetes. Over the last decade, insights into beta cell development, combined with the deeper research of related donor stem cells including ESCs, iPSCs and pancreatic progenitors, have led us to generate functional beta cells. Besides, several alternative approaches have also converted other cell types into insulin positive beta-like cells via lineage reprogramming factors (Pdx1, Nkx6-1, Pax4 and Ngn3). Nowadays, people realized that advances in investigating of beta cell biology at the genomic and post-transcription levels are more useful in deeply understanding the cells source, behavior and function. For research in drug screening or diabetes transplantation therapy, herein, we reviewed the recent information about development, replication of beta cells, and production of insulin-positive cells via lineage reprogramming or small molecule treatment.
\end{abstract}

\section{Introduction}

The pancreas was reported to serve two major regulatory functions, including production of digestive enzymes and regulation of blood sugar, which is achieved by endocrine cells of the islets of Langerhans (also called pancreatic

International Journal of Translational Science, Vol. 1, 41-66.

doi: 10.13052/ijts2246-8765.20151004

(c) 2016 River Publishers. All rights reserved. 
islets). In adult human beings, there are $60-80 \%$ beta cells residing in islets, secreting insulin, an important regulatory hormone of in the regulation of carbohydrate and fat metabolism [1]. Since the discovery of insulin in 1922, the pancreatic beta cell has been a major focus in the study of diabetes. Until present, it is well known that the blood high glucose levels, and a metabolic disorder in diabetes are resulted from insufficient amount of insulin committed by beta cell death and dysfunction [2]. Recent genetic and clinical studies have highlighted the role of beta cell failure in diabetes pathogenesis [3]. Despite the loss of beta cell number in type I diabetes and deficient beta cell function in type II diabetes, few existing drugs are effective at protecting or restoring this cell type in humans [4]. Both Type I and type II diabetes mellitus are characterized by progressive beta cell failure [5].

Currently, most efforts are aiming at looking for other alternative beta cell sources. As the beta cell is a key cell type in advancing the promise of regenerative medicine. Transplantation and regeneration based on cell therapy strategies are considered as potential therapeutic alternative instead of traditional diabetes treatments [6]. Successful islets and whole pancreas transplantations have already proved that the insufficient insulin could be restored by replenishment of functional beta cell [7, 8]. However, there are not enough healthy beta cell sources, current research groups are focusing on suitable strategies promoting the replication of pre-existing beta cell progenitors and naive stem cells or transdifferentiation from adult cells $[9,10]$. Hence, the production of functional insulin-positive cells from stem/progenitor cells represents one of the most promising scientific avenues, present research attempted to dig and imitate beta cell development in vitro [11].

Moreover, advances in high-throughput screening have enabled a modern focus on identifying novel small molecules that are capable of inducing beta cell proliferation and insulin secretion, reprogramming from other cell types [12-15]. To gain deeper insight of the molecular regulatory network guiding endocrine cell differentiation during pancreas development and increase our understanding of the related cellular transcriptional factors expression levels and signaling pathways activities will be useful when treating diabetes by regeneration of beta cell both in vitro or in vivo $[16,17]$.

\section{Diabetes}

Since complicated genetic and environmental factors are reported to induce the loss of functional beta cell population, strict clinical definitions of diabetes usually obscure different mechanistic subtypes [18]. Nevertheless, diabetes 
can be generally divided into two subtypes including type I (T1D) caused by the absence of insulin-producing beta cells and type II (T2D) which is resulted from a failure in insulin production [3,5]. In type II, it is sometimes similar with type I which can be recognized as loss of beta cells mass due to insulin resistance [19]. Without long-term treatment, hyperglycemia in type I diabetes patient could lead to other irreversible complications, such as blindness, renal failure, foot amputation and serious cardiovascular diseases [8]. The reason of functional beta cell loss are different among these subtypes of the disease [20]. With the related researches development, I believe that detailed classifications of diabetes will be accepted. Even so, both I and II types have already been characterized by progressive beta cell failure. In type I diabetes, beta cell death is typically caused by an autoimmune assault. However, the T2D etiology is more highly variable, beta cell failure is due to varying degrees of insulin resistance $[13,21]$.

\subsection{Subtypes of Diabetes}

Nowadays, one million people each year suffering T1D, and it is one of the leading causes of blindness, nephropathy, and heart disease [22]. It is believed that T1D is induced by the autoimmune attack against the islets and most frequently occurs during childhood or adolescence [23]. This form of diabetes is suggested to be induced by a complex combination of genetic and environmental factors. There are about $50 \%$ genetic influence happening is HLA class II genes which is believed important for T1D [8]. Not like T1D, T2D is reported determined by genetics according to many family genetic investigations. Data from genome analysis displayed that T2D patient special loci usually contained genes related to beta cell formation and function, but few to do with insulin resistance [18]. Moreover, there is another subtype of diabetes caused by a single gene mutation has been called maturity-onset diabetes of the young (termed MODY) [24].

\section{Replication and Function of Beta Cell}

Connecting with the duodenum, pancreas plays as a regulator role by producing enzymes to digest foods and hormones to sustain proper blood sugar levels, respectively $[2,25]$. The mixed gland is mainly composed consists of two types of glandular tissue: exocrine acini and endocrine islets. [1, 10, 26]. The acinar cells are responsible for producing and secreting digestive enzymes such as lipases, proteases and nucleases. Both acinar and duct cells belong to 
pancreatic exocrine part. The endocrine cells are mainly involved in regulating glucose homeostasis and nutrient metabolism. Specifically, the endocrine part of pancreas is usually existed in many small cell clusters of islets, which scattered and detached throughout the pancreatic tissue, and are composed by five cell subtypes such as alpha, beta, delta, eta and PP cells, each of them secretes a particular factor including glucagon, insulin, somatostatin, ghrelin, and pancreatic polypeptide, respectively [27, 28]. Importantly, insulin and glucagon act coordinately to maintain the balance of blood sugar [29, 30]. In this section, we briefly introduce the genetic factors (transcription factors and microRNAs) involved in mass formation, regeneration and insulin secretion of beta cells.

\subsection{Pancreatic Development and Transcription Factors}

\subsubsection{Development of pancreas}

Mouse models are usually employed in organ development research. During murine embryonic development, the pancreas develops from the endoderm $[1,31]$. The earliest morphological evidences for the pancreas formation can be observed E9.5 [32]. Specifically, there are two outgrowths of the developing pancreas (pancreatic buds) arising along the dorsal and ventral axis. Their appearances are uncoordinated, the dorsal bud can be observed at E9.0, but the ventral bud appears at E9.5 [33]. Then, the latter pancreas morphogenesis consists of two overlapping sections including the primary and secondary transitions [34]. During pancreas development, all exocrine and endocrine lineages are derived from a same population of multipotent progenitors. These pancreatic progenitors proliferation are promoted in primary transition [35]. The secondary transition is responsible for deciding these progenitors towards different lineages [36]. From E13, epithelium expands extensively and mature endocrine cells including beta cells appear after the expression Ngn3, an early marker of pancreatic precursors [37]. And the final formation time point of islets of Langerhans is at shortly after birth (E15) [38, 39].

\subsubsection{Key transcription factors in endocrine cells formation}

During the early development, programmed expressions of specific transcription factors (TFs) are activated and will determine the differentiation directions of multiple tissues including pancreatic endocrine part [36, 40]. The lineage-tracing studies and TF specific knock-out analyses enhanced our understanding of the molecular mechanisms regulating pancreatic endocrine 
development and to confirm the related key TFs at different stages during pancreatic formation [41] (as shown in Figure 1).

Pancreatic and duodenal homeobox 1 ( $\mathrm{Pdx} 1)$, also known as insulin promoter factor 1 , is the most famous TF identified for its decisive effect during pancreatic development [42]. However, recent study reported that $\mathrm{Pdx} 1$ are mainly responsible for the pancreatic buds formation but not affect the following endocrine differentiation [43]. In both mice and humans the early expression of Pdx 1 arise at E8.5 in the dorsal and ventral pancreatic endoderm and continues until E12.5 [46], absence of Pdx1 causes pancreas agenesis at birth $[44,45]$. In addition, expression of $\mathrm{Pdx} 1$ persistes in mature endocrine cells, it is necessary for the maturation and survival of beta cell, its disappearance promotes a significant decrease in beta cell numbers [47, 48].

Besides, there are several important TFs also involved in the allocation towards the endocrine lineage. The pancreatic buds contain undifferentiated progenitors cells with bipotentiality into endocrine and ductal tissues. It was reported that the endocrine-lineage differentiation of these progenitors requires Ngn3 which belongs to the basic helix-loop-helix (bHLH) transcription factors [37, 49]. Ngn3, expressing from E8.5 to E15.5, is usually

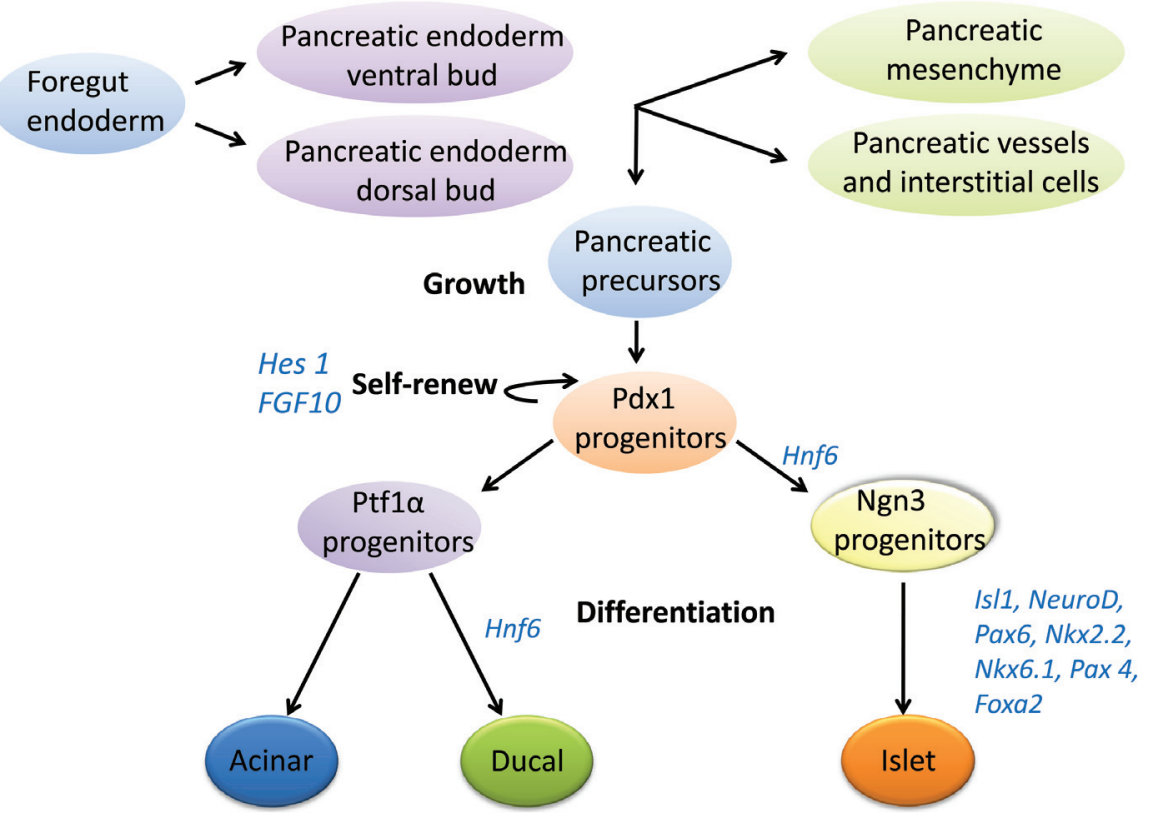

Figure 1 Key transcription factors in endocrine lineages. 
considered as a marker for early pancreatic progenitors (termed Ngn3 precursors) [37]. Mice lacking Ngn3 could not form endocrine cells. Ngn3 expression could be induced by $\operatorname{Pdx} 1$, then activate the differentiation of pancreatic bud progenitors towards endocrine direction [37]. Indeed, some other important regulatory TFs expression such as Arx, Pax4, NeuroD1, Nkx2.2, and Nkx6.1 require the activation of $\mathrm{Ngn} 3$, which enhance the maturity of endocrine precursors [50-54]. Nkx2.2 and Nkx6.1, which both belong to the NK family, were confirmed to play different essential roles in formation of beta cells and insulin secretion $[53,55]$. Nkx2.2 expression is unregulated at E9.5 and persists in islet mature cells except delta cells. Knock out of Nkx2.2 reduces in number of mature beta cell mass. Similarly, mice lacking Nkx6.1 was reported to lead to loss of beta cells mass [54].

Except for the classical TFs, it is already shown that some other downstream TFs are required for the specific differentiation towards endocrine lineage, including Arx, Pax4, Pax6, MafA, MafB, and NeuroD1 [36]. Pax4, a member of the paired box (PAX) family of transcription factors, appears at E9.5 and gradually expresses restricted to mature beta cells in mouse [51]. It is involved in islet formation, mouse studies have demonstrated a role for this gene in lineage determination of insulin producing beta cells, thus, neonatal hyperglycemia was found in mice ${ }^{\mathrm{Pax} 4-/-}$. Different from Pax4, the Arx gene is transcribed at E9.5 and restricted to alpha and PP cells [50]. Tissue-specific knocking-down of Arx in islets increased beta cell population by transdifferentiation from alpha cell to beta cell. Deep research has already indicated that Arx and Pax 4 form an inhibitory cross regulatory circuit to affect the endocrine precursors fate as their antagonistic activities [50, 56]. Pax6, also known as aniridia type II protein (AN2) or oculorhombin, can be detected in all three islet cell types. Murine knocking-off study showed Pax6 is required for the entire islet cell number [57, 58]. MafA and MafB, both belonging to the basic leucine-zipper TFs, are also required for alpha and beta cell maturation $[59,60]$. MafA remains specially in beta cell [61], whereas MafB is critical for both alpha and beta cell formation and maturation [62]. Moreover, NeuroD is an important TF during pancreatic development, it is necessary during the beta cells formation and their regulatory function in sustaining the blood glucose after birth $[52,63]$.

\subsubsection{Transcription factor-based lineage reprogramming}

Based on the research targeting genetic network during beta cell development, reprogramming other cells via the forced expression of some key developmental TFs have achieved insulin-producing beta cells by directional 
differentiation and transdifferentiation (Figure 2). In theory, embryonic stem cells (ESCs) with pluripotency are able to differentiate to any adult cell types. It has already been shown that human ESCs can be directly differentiated into mature beta cells by a stepwise approach in vitro [64]. However, this process is tedious, easy to pollute and prone to immunological rejection when used [65-67]. Sharing similar characteristics with ESCs, the induced pluripotent stem cells (iPSCs) from patients themselves provide us an ideal source for beta cell transplantation with lower risk [68]. Early studies focused on the conversion of hepatocytes to beta like cells through the overexpression of Pdx1, MafA and NeuroD [69-71]. However, the immature cells in their reports cannot produce insulin since silence of some key functional factors. Accordingly, viral-mediated delivery of Pdx, Ngn3 and MafA reprogrammed the acinar cells of nude mice into insulin-positive cells $[72,73]$. Through the ectopic expression of $\mathrm{Pax} 4$, pancreatic $\mathrm{Pdx} 1$ progenitors cells reprogrammed

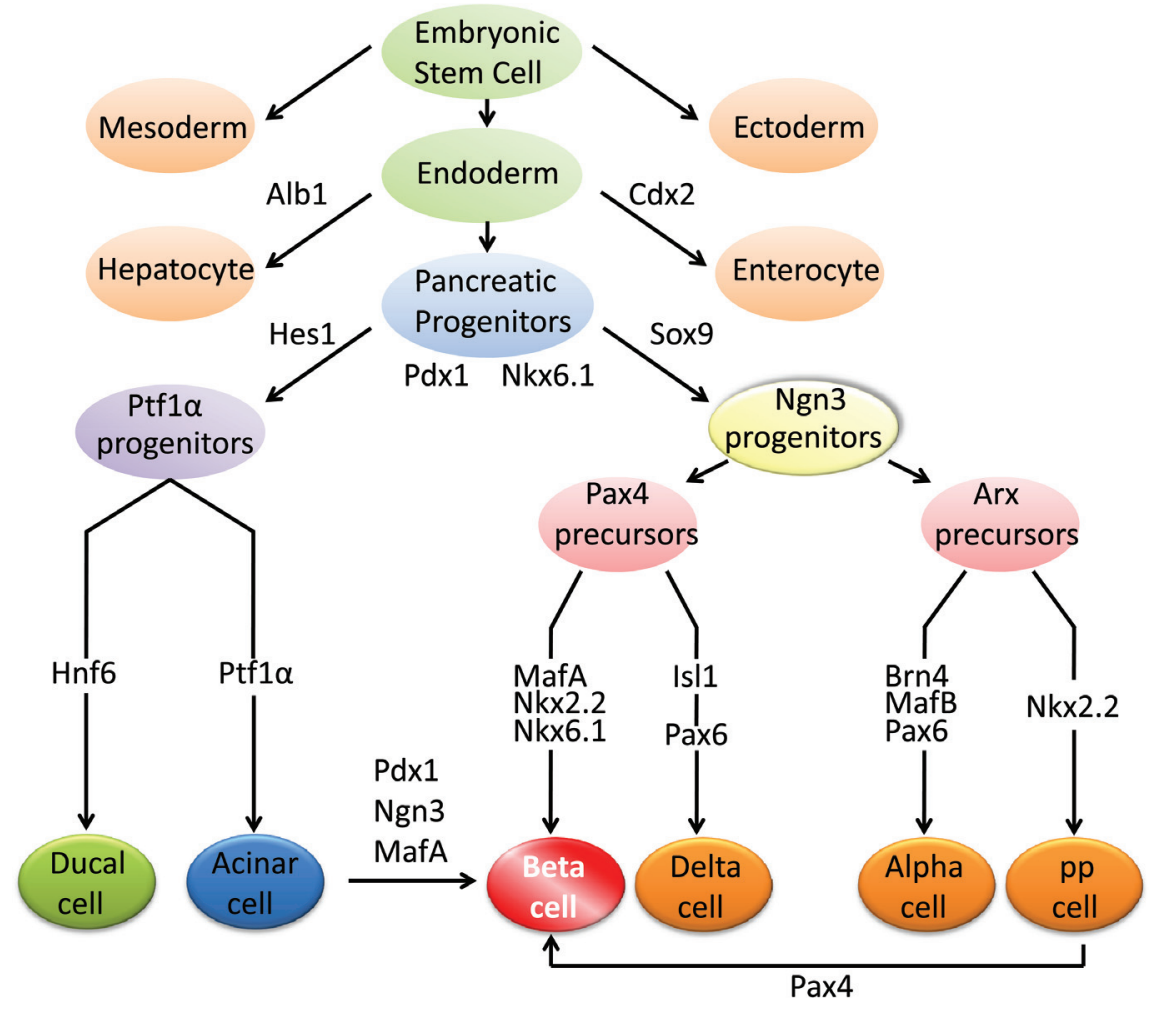

Figure 2 Generation of beta-cell like by reprogramming. 
into glucagon-positive alpha cells [74]. Interestingly, PP cell could be transdifferented to beta-cell like via forceful expression of a single gene, Pax4. However, in the case of T1D, such generated beta cells cells would be targets for autoimmunity and this approach may also bring tumor risk [14].

\subsection{Insulin Production and Secretion}

As a common regulator in blood, muscle and fat tissues, insulin is mainly involved in metabolism of carbohydrates and fat. It belongs to a peptide hormone and is produced as part of a larger precursor inactive protein (preproinsulin), which is initially translated [25]. An amino-terminal signal sequence in preproinsulin is needed for passing the endoplasmic reticulum membrane, in which precursor hormone will be post-translational processed [77]. When secreted into the endoplasmic reticulum, the N-terminal signal sequence on preproinsulin will be cut off [75], and disulfide bonds will form to bridge A- and B- chains [76]. Then, the polypeptide is cleaved at two positions to release the intervening chain $\mathrm{C}$ [78]. Lastly, the post-translational formation of three vital disulfide bonds occurs, specific peptidases act to cleave proinsulin producing the final functional insulin [16]. At the same time, insulin is mainly stored in secretory granules waiting for release [79].

Normally, secretion of insulin is triggered by sensing changes in ambient glucose levels with two phases, including the first phase occurring in the first few minutes, followed by a more enduring second phase [80]. Briefly, glucose is transported into the cell with specific transporters, where it is phosphorylated by glucokinase and converted into ATP by succedent metabolic reactions. The rise of intracellular ATP levels triggers the closure of $\mathrm{K}^{+}$channels, membrane depolarization and the opening of $\mathrm{Ca}^{2+}$ channels. The resultant rise in intracellular $\mathrm{Ca}^{2+}$ levels induces the exocytosis of insulin-positive granules and increases insulin levels in blood [81, 82] (Figure 3).

\subsection{MicroRNAs Involved in Beta Cell Fate and Insulin Secretion}

MicroRNAs (miRNAs) are small noncoding molecules which negatively regulate gene expression by inhibiting their target genes [83]. Emerging studies have shown that miRNAs play diverse roles in diabetes. The present study confirmed the miRNAs that controlled insulin release and production by affecting cell membrane electrical excitability, insulin synthesis, insulincontaining granule exocytosis and beta cell formation [84, 85]. For instance, miR-375 is essential for the formation of pancreatic islets and maintains the 


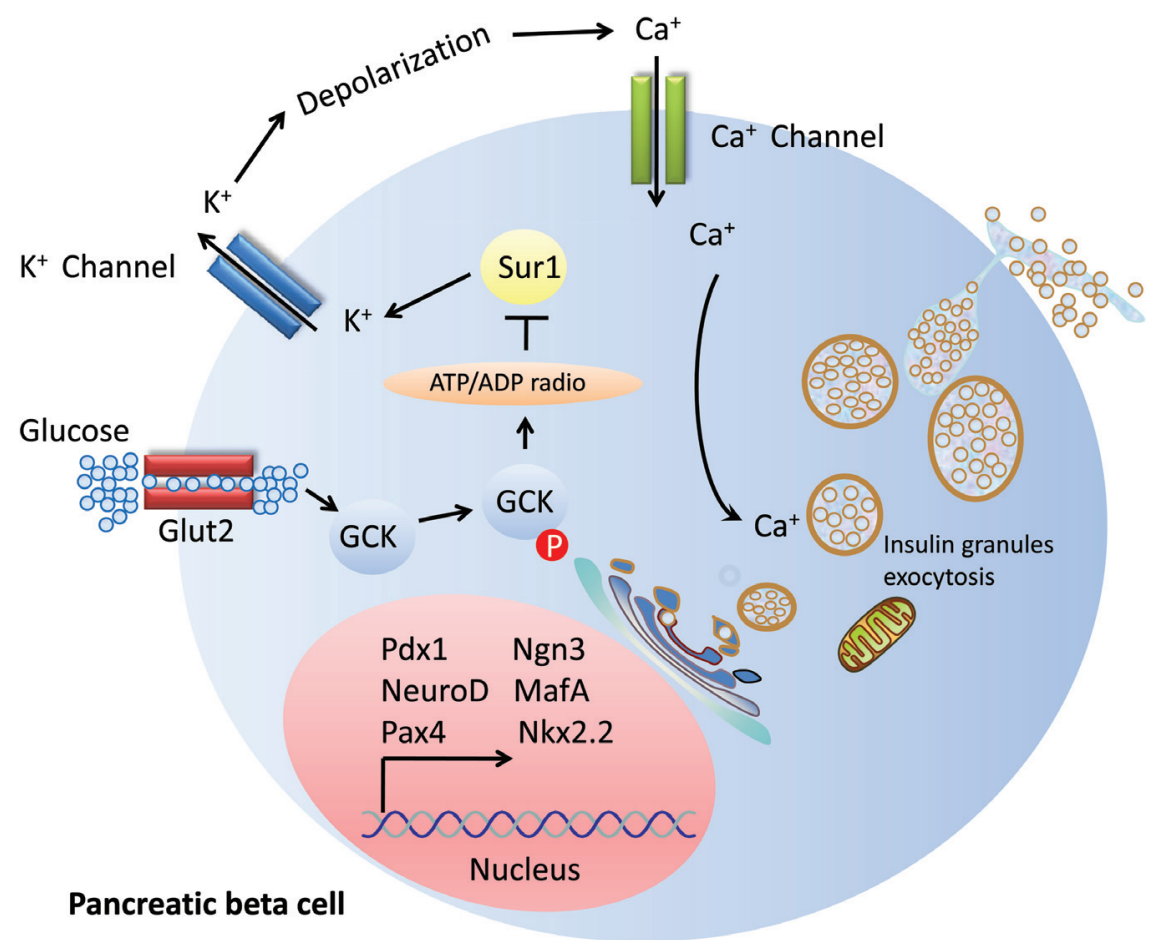

Figure 3 Glucose-stimulated insulin secretion.

mass of pancreatic alpha and beta cells. miR-15a could repress the uncoupling protein gene Ucp2 directly, which is an important regulator in functional beta cell, it reduces ATP levels, resulting in decrease of ATP/ADP ratio and subsequently decreases glucose-stimulated insulin secretion [86, 87]. miR-29a and miR-29b also negatively control insulin release by reducing the monocarboxylate transporter 1 (Mct1), which acts as a substrate for mitochondrial oxidation to increase cytosolic ATP/ADP ratio and triggers insulin release [88]. miR-124a targets on Foxa2, regulating the KATP channel subunits, Kir6.2 and Sur-1 and pancreatic development [89]. Importantly, in pancreatic cell fate and pancrease formation, miR-21 targets Pdcd4 and induces cell death through the Bax family of apoptoticproteins [90]. miR146 contributes to the enhancement of free-acid induced beta cell apoptosis [91]. Besides, our research has also confirmed that miR-375 participating in pancreatic progenitors proliferation via targeting Yap1, miR-18a regulating 


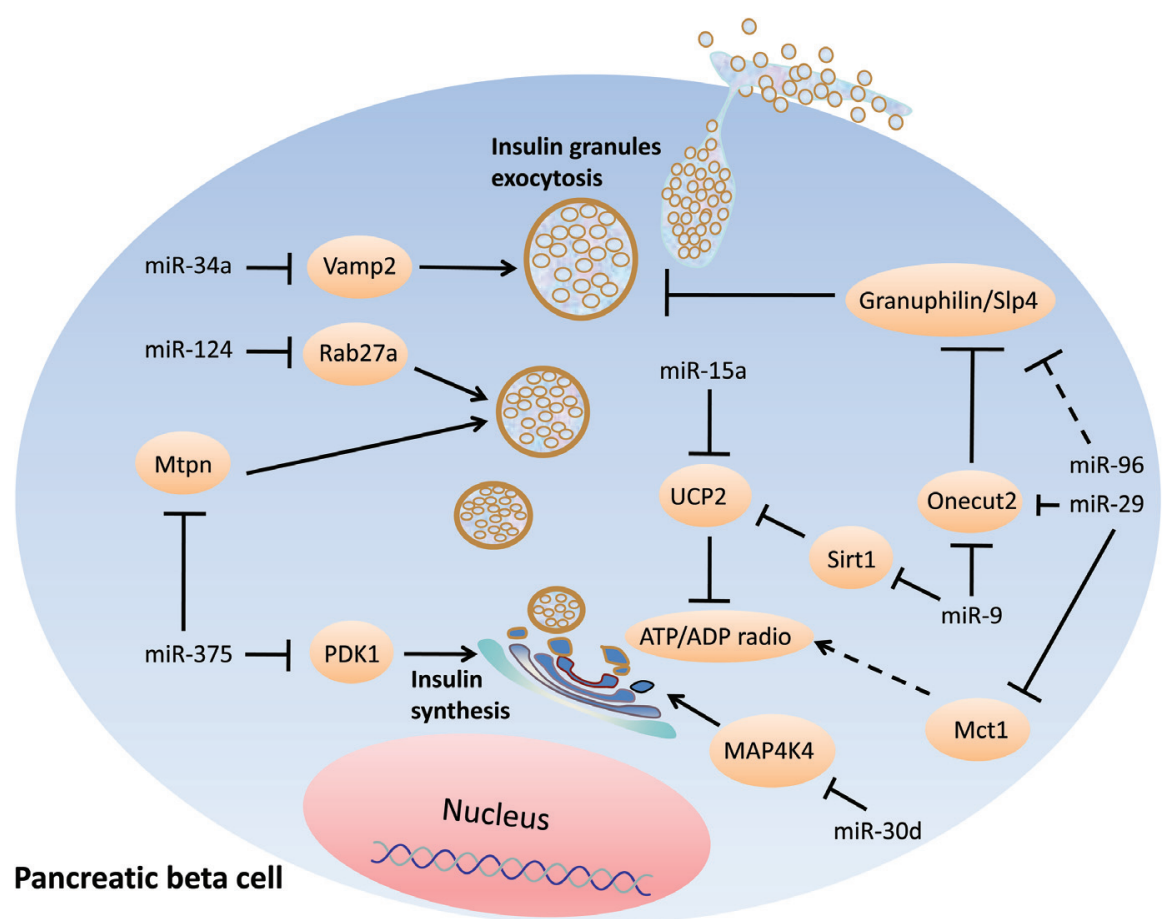

Figure 4 miRNAs involved in insulin release in pancreatic beta cells and beta cell fate.

Ptf1a involved in progenitors stemness, and miR-19b which belongs to miR17-92 cluster could down-regulate insulin 1 by directly repressing NeuroD1 [92-94]. (Figure 4).

\subsection{Beta Cell Death and Apoptosis in Diabetes}

In T1D, beta cell mass is usually reduced by $70-80 \%$ when found [6]. Since the obscure insulitis and undetectable beta cell necrosis, it was supposed that the loss of beta cell mass occurs slowly [8]. Initial pathological studies suggested there was a beta cell loss of $25-50 \%$ in T2D, while recent reports pointed us that a significant reduction in beta cell mass and an increase in beta cell apoptosis occurs [95]. Although, persuasive data confirmed that both T1D and T2D sharing the same phenotype with appearance of high level inflammatory mediators expression, such as cytokine interleukin IL-1, inducing beta cell apoptosis, mass loss and diabetes [96]. For protection beta cell from cytokine-induced apoptosis, approaches based on both genetic and 


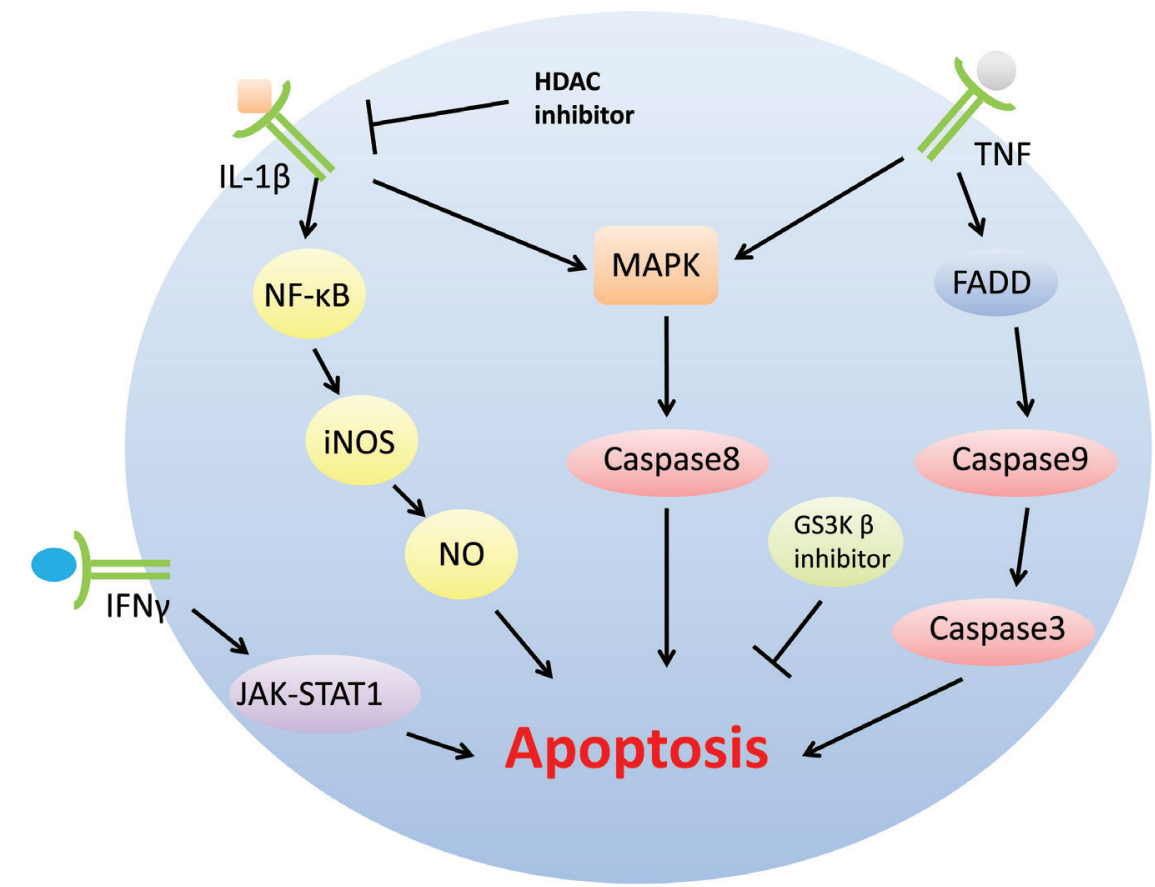

Pancreatic beta cell

Figure 5 Beta cell apoptosis.

small-molecule have been tested $[19,97]$. The NF-кB pathway activity has been genetically weakened by ectopic expression of a degradation-resistant NF- $\kappa$ B protein inhibitor, and knockdown of STAT1 in rodent beta cell lines also obviously inhibited apoptosis [98]. Small molecule-based approaches have already tested to weaken the JAK-STAT signalling via silymarin, and HDACs using isoform-selective inhibitors to prevent beta cell dysfunction in human islets [99]. Besides, high levels of glucose and free fatty acids were also reported able to induce endoplasmic reticulum stress and reduce beta cell function and viability [100]. These effects may be suppressed by antioxidants, GS3K $\beta$ inhibitors and HDAC inhibitors mentioned above. (Figure 5).

\subsection{Pancreatic Beta Cell Regeneration}

After birth, most beta cells mass expansion considerably slows down, however, it has been shown that the beta cell mass can expand under some physiologic or pathologic stimulations including pregnancy and obesity [101-103]. In murine 
models, there is also evidence showing the pancreas preserves the ability to regenerate its beta cell population in response to several non-physiological injuries, for example, low-dose injection of streptozotocin (a chemical drug for specifically killing beta cell) will promote beta cell progenitors reproduction $[104,105]$. As reported, several progenitors residing in ductal and nonductal tissues have been shown as potential sources for beta cell renewal $[106,107]$. In addition, progenitors from other organs, such as liver, bone marrow and adipose have been considered as either potential sources of islets [108-110]. However, persuasive evidences regarding neogenesis and selfrenew for maintenance the normal of beta cells mass still need to be supported.

Besides genetic reprogramming strategies for production of insulinpositive beta cells, small molecules treatment without genome alteration attract more attentions. Different kinds of small molecules could activate or inactivate certain factors, studies of chemical screening confirmed some small molecules could promote the programming of pluripotent stem cells and reprogramming somatic cells into functional beta cells [14]. Recently, our partner group Deng et al. showed that it is possible to generate iPSCs from mouse somatic cells with compound small molecules with no gene modification [111]. The versatile differentiating agentretinoic acid enhanced the generation of Pdx1-positive progenitors from human ESCs and also enhanced further differentiation into insulin-producing beta cells [112]. A small molecule Indolactam V could direct the differentiation of human ESCs into Pdx1expressing cells [113]. Addition of BRD7552 can also upregulate expression of Pdx1 by epigenetically altering Pdx1 promoter area in human cells [114]. In mice, the TGF-beta signalling pathway activating small molecules (IDE-1 and IDE2) are able to induce pancreatic progenitors from mouse ESCs when used along with Indolactam V [15]. Swerstin has ability to reprogram murine NIH3T3 cells into islet-like clusters [115]. Antoher small molecular called WS6 is capable to promote beta cell proliferation in human [116]. Thus, when treated with four small molecules together including selenite, 5-AZA, RA and TSA, liver stem-like WB cells turned directly into beta cells [117].

\section{Clinical Islets Transplantation for Diabetes}

Until present, there're mainly two types of transplantation successfully treating diabetes including allo-transplantation and auto-transplantation. The allo-type is a procedure in which islets from deceased organ donor are purified and transferred into patients with T1D [118]. However, patients usually have 
to take two or more transplants to obtain enough functioning islets to bring blood sugar levels back to normal. The second type is performed for patients after whole pancreatectomy. The patient's own islets are infused to their livers [27]. This type is not suitable in T1D [8]. The transplantation of islets can alleviate insulin dependence for T1D, however, due to the limitation of immune suppression therapies and the shortage of islet donors, this approach remains in little popularity $[6,119]$. Interestingly, there is another sub-type of allo-transplantation called whole pancreas transplantation which has been well established for reversing severe T1DM [120].

\section{Conclusions}

Aiming to establish new therapeutic applications for diabetes, many studies are targeting at the mechanisms of beta cell function, proliferation and differentiation. This present comprehensive review describes the advances in the field of recent potential therapy approaches based on beta cell transplantation and small molecule treatment, thus, the background information is also summarized including beta cell development, replication and regeneration. Recently, a spurt of progress has been made towards both understanding how beta cells form and proliferate during development and how functional beta cells might be generated. Advances in our understanding of beta cell behavior at the genomic and post-transcription levels will be useful for defeating diabetes mellitus.

\section{Acknowledgments}

This work was supported by the Fundamental Research Funds for the Central Universities (No. 2572015BA06), National Nature Science Foundation of China (No. 31502030), and Heilongjiang Postdoctoral Grant (No. LBH-Z14018).

\section{References}

[1] Petkov, P. E., and A. Vitanov. 1962. Development of connective tissue near the pancreatic islets of Langerhans in the human fetus. Nauchni Tr. Vissh. Med. Inst. Sofiia 41: 91-108.

[2] Heinze, E., and J. Steinke. 1972. Insulin secretion during development: response of isolated pancreatic islets of fetal, newborn and adult rats to theophylline and arginine. Horm. Metab. Res. 4(4): 234-236. 
[3] Naya, F. J., H. P. Huang, Y. Qiu, H. Mutoh, F. J. DeMayo, A. B. Leiter, and M. J. Tsai. 1997. Diabetes, defective pancreatic morphogenesis, and abnormal enteroendocrine differentiation in BETA2/neuroD-deficient mice. Genes Dev. 11(18): 2323-2334.

[4] Yamaoka, T., and M. Itakura. 1999. Development of pancreatic islets (review). Int. J. Mol. Med. 3(3): 247-261.

[5] Nathan, D. M. 1993. Long-term complications of diabetes mellitus. N. Engl. J. Med. 328(23): 1676-1685.

[6] Daneman, D. 2002. Islet cell transplantation and other new technologies for treating type 1 diabetes: a paediatric view. Horm. Res. 57(1): 54-59.

[7] Serup, P., O. D. Madsen, and T. Mandrup-Poulsen. 2001. Islet and stem cell transplantation for treating diabetes. BMJ 322: 29-32.

[8] Liu, E. H., K. I. Rother, and D. M. Harlan. 2005. Islet transplantation and the challenges of treating type 1 diabetes. Discov. Med. 5(25): 43-49.

[9] Yang, L., S. Li, H. Hatch, K. Ahrens, J. G. Cornelius, B. E. Petersen, and A. B. Peck.2002. In vitro trans-differentiation of adult hepatic stem cells into pancreatic endocrine hormone-producing cells. Proc. Natl. Acad. Sci. USA, 99(12): 8078-8083.

[10] Lacy, P. E. and D. W. Scharp. 1986. Islet transplantation in treating diabetes. Annu. Rev. Med. 37: 33-40.

[11] Efrat, S. 2008. Beta-cell replacement for insulin-dependent diabetes mellitus. Adv. Drug. Deliv. Rev. 60(2): 114-123.

[12] Collombat, P., X. Xu, H. Heimberg, and A. Mansouri. 2010. Pancreatic beta-cells: from generation to regeneration. Semin. Cell Dev. Biol. 21(8); 838-844.

[13] Ashcroft, F. M., and P. Rorsman. 2012. Diabetes mellitus and the beta cell: the last ten years. Cell, 148(6): 1160-1171.

[14] Ben-Othman, N., M. Courtney, A. Vieira, A. Pfeifer, N. Druelle, E. Gjernes, B. Faurite, F. Avolio, and P. Collombat. 2013. From pancreatic islet formation to beta-cell regeneration. Diabetes Res. Clin. Pract. 101(1): 1-9.

[15] Borowiak, M., R. Maehr, S. Chen, A. E. Chen, W. Tang, J. L. Fox, S. L. Schreiber, and D. A. Melton. 2009. Small molecules efficiently direct endodermal differentiation of mouse and human embryonic stem cells. Cell Stem Cell, 4(4): 348-358.

[16] Oliver-Krasinski, J. M., and D. A. Stoffers. On the origin of the beta cell. Genes Dev. 22(15): 1998-2021.

[17] Desgraz, R., C. Bonal, and P. L. Herrera. 2011. beta-cell regeneration: the pancreatic intrinsic faculty. Trends Endocrinol. Metab. 22(1): 34-43. 
[18] Caro, J. J., A. J. Ward, and J. A. O'Brien. 2002. Lifetime costs of complications resulting from type 2 diabetes in the U.S. Diabetes Care, 25(3); 476-481.

[19] Rhodes, C. J. 2005. Type 2 diabetes-a matter of beta-cell life and death? Science, 307(5708): 380-384.

[20] Kassem, S., S. Bhandari, P. Rodriguez-Bada, R. Motaghedi, M. Heyman, M. A. Garcia-Gimeno, N. Cobo-Vuilleumier, P. Sanz, N. K. Maclaren, J. Rahier, B. Glaser, and A. L. Cuesta-Munoz. 2010. Large islets, betacell proliferation, and a glucokinase mutation. N. Engl. J. Med. 362(14): 1348-1350.

[21] Cnop, M., N. Welsh, J. C. Jonas, A. Jorns, S. Lenzen, and D. L. Eizirik. 2005. Mechanisms of pancreatic beta-cell death in type 1 and type 2 diabetes: many differences, few similarities. Diabetes, 54(2): S97-S107.

[22] Zhang, C., W. Bao, Y. Rong, H. Yang, K. Bowers, E. Yeung, and M. Kiely. 2016. Genetic variants and the risk of gestational diabetes mellitus: a systematic review. Hum. Reprod. Update, 19(4): 376-390.

[23] Bluestone, J. A., K. Herold, and G. Eisenbarth. 2010. Genetics, pathogenesis and clinical interventions in type 1 diabetes. Nature, 464(7293): 1293-1300.

[24] Liu, Y., A. Kumar, D. W. Boykin, and W. D. Wilson. 2007. Sequence and length dependent thermodynamic differences in heterocyclic diamidine interactions at AT base pairs in the DNA minor groove. Biophys. Chem. 131: 1-14.

[25] Adrian, T. E., S. R. Bloom, K. Hermansen, and J. Iversen. Pancreatic polypeptide, glucagon and insulin secretion from the isolated perfused canine pancreas. Diabetologia, 14(6): 413-417.

[26] Sak, M. F., I. A. Macchi, and S. B. Beaser. 1965. Postnatal Development of Beta Cells and Ila Secretion in the Pancreatic Islets of the Golden Hamster. Anat. Rec. 152: 25-33.

[27] Vantyghem, M. C., F. Defrance, D. Quintin, C. Leroy, V. Raverdi, G. Prevost, R. Caiazzo, J. Kerr-Conte, F. Glowacki, M. Hazzan, C. Noel, F. Pattou, A. S. Diamenord, R. Bresson, M. F. Bourdelle-Hego, M. Cazaubiel, M. Cordonnier, D. Delefosse, F. Dorey, A. Fayard, C. Fermon, P. Fontaine, C. Gillot, S. Haye, A. C. Le Guillou, W. Karrouz, C. Lemaire, M. Lepeut, R. Leroy, B. Mycinski, E. Parent, C. Siame, A. Sterkers, F. Torres, O. Verier-Mine, E. Verlet, R. Desailloud, A. Durrbach, M. Godin, J. D. Lalau, C. Lukas-Croisier, E. Thervet, O. Toupance, Y. Reznik, and P. F. Westeel. 2014. Treating diabetes with 
islet transplantation: Lessons from the past decade in Lille. Diabetes Metab. 40(2): 108-119.

[28] Kornete, M., H. Beauchemin, C. Polychronakos, and C. A. Piccirillo. 2013. Pancreatic islet cell phenotype and endocrine function throughout diabetes development in non-obese diabetic mice. Autoimmunity, 46(4): 259-268.

[29] Bocian-Sobkowska, J., M. Zabel, W. Wozniak, and J. Surdyk-Zasada. 1997. Prenatal development of the human pancreatic islets. Immunocytochemical identification of insulin-, glucagon-, somatostatin- and pancreatic polypeptide-containing cells. Folia Histochem. Cytobiol. 35(3): 151-154.

[30] Kim, S. H., F. Abbasi, C. Lamendola, G. M. Reaven, and T. McLaughlin. 2010. Glucose-stimulated insulin secretion in gastric bypass patients with hypoglycemic syndrome: no evidence for inappropriate pancreatic beta-cell function. Obes. Surg. 20(8); 1110-1116.

[31] Spooner, B. S., B. T. Walther, and W. J. Rutter. 1970. The development of the dorsal and ventral mammalian pancreas in vivo and in vitro. J. Cell Biol. 47(1): 235-246.

[32] Slack, J. M. 1995. Developmental biology of the pancreas. Development, 121(6): 1569-1580.

[33] Kim, S. K. and D. A. Melton. 1998. Pancreas development is promoted by cyclopamine, a hedgehog signaling inhibitor. Proc. Natl. Acad. Sci. USA, 95(22): 13036-13041.

[34] Pictet, R. L., W. R. Clark, R. H. Williams, and W. J. Rutter. An ultrastructural analysis of the developing embryonic pancreas. Dev. Biol. 29(4): 436-467.

[35] Edlund, H. 2001. Developmental biology of the pancreas. Diabetes, 50(1): 5-9.

[36] Rieck, S., E. D. Bankaitis, and C. V. Wright. 2012. Lineage determinants in early endocrine development. Semin. Cell Dev. Biol. 23(6): 673-684.

[37] Gu, G., J. Dubauskaite, and D. A. Melton. 2002. Direct evidence for the pancreatic lineage: NGN3+ cells are islet progenitors and are distinct from duct progenitors. Development, 129(10): 2447-2457.

[38] Vignjevic, S., V. Todorovic, S. Damjanovic, M. Budec, O. Mitrovic, D. Djikic, N. Drndarevic, M. Micic, J. Miskovic-Krivokapic, S. Djuricic, and I. Nikolic. 2012. Similar developmental patterns of ghrelin- and glucagon-expressing cells in the human pancreas. Cells Tissues Organs, 196(4): 362-373. 
[39] Benitez, C. M., W. R. Goodyer, and S. K. Kim. 2012. Deconstructing pancreas developmental biology. Cold Spring Harb. Perspect. Biol. 4(6). doi: 10.1101/cshperspect.a012401.

[40] Chen, C. Z., L. Li, H. F. Lodish, and D. P. Bartel. 2004. MicroRNAs modulate hematopoietic lineage differentiation. Science, 303(5654): 83-86.

[41] Cano, D. A., B. Soria, F. Martin, and A. Rojas. 2014. Transcriptional control of mammalian pancreas organogenesis. Cell Mol. Life Sci. 71(13): 2383-2402.

[42] Offield, M. F., T. L. Jetton, P. A. Labosky, M. Ray, R. W. Stein, M.A. Magnuson, B. L. Hogan, and C. V. Wright. 1996. PDX-1 is required for pancreatic outgrowth and differentiation of the rostral duodenum. 1996. Development, 122(3): 983-995.

[43] McKinnon, C. M. and K. Docherty. 2001. Pancreatic duodenal homeobox-1, PDX-1, a major regulator of beta cell identity and function. Diabetologia, 44(10): 1203-1214.

[44] Holland, A. M., L. J. Gonez, G. Naselli, R. J. Macdonald, and L. C. Harrison. 2005. Conditional expression demonstrates the role of the homeodomain transcription factor Pdx1 in maintenance and regeneration of beta-cells in the adult pancreas. Diabetes, 54(9): 2586-2595.

[45] Gannon, M., E. T. Ables, L. Crawford, D. Lowe, M. F. Offield, M. A. Magnuson, and C. V. Wright. 2008. pdx-1 function is specifically required in embryonic beta cells to generate appropriate numbers of endocrine cell types and maintain glucose homeostasis. Dev. Biol. 314(2): 406-417.

[46] Gao, N., J. LeLay, M. Z. Vatamaniuk, S. Rieck, J. R. Friedman, and K. H. Kaestner. 2008. Dynamic regulation of Pdx 1 enhancers by Foxa1 and Foxa2 is essential for pancreas development. Genes Dev. 22(24): 3435-3448.

[47] Kajiyama, H., T. S. Hamazaki, M. Tokuhara, S. Masui, K. Okabayashi, K. Ohnuma, S. Yabe, K. Yasuda, S. Ishiura, H. Okochi, and M. Asashima. 2010. Pdx1-transfected adipose tissue-derived stem cells differentiate into insulin-producing cells in vivo and reduce hyperglycemia in diabetic mice. Int. J. Dev. Biol. 54(4): 699-705.

[48] Kaneto, H., Y. Nakatani, T. Miyatsuka, T. A. Matsuoka, M. Matsuhisa, M. Hori, and Y. Yamasaki. 2005. PDX-1/VP16 fusion protein, together with NeuroD or Ngn3, markedly induces insulin gene transcription and ameliorates glucose tolerance. Diabetes, 54(4): 1009-1022. 
[49] Gradwohl, G., A. Dierich, M. LeMeur, and F. Guillemot. 2000. Neurogenin3 is required for the development of the four endocrine cell lineages of the pancreas. Proc. Natl. Acad. Sci. USA, 97(4): 1607-1611.

[50] Collombat, P., A. Mansouri, J. Hecksher-Sorensen, P. Serup, J. Krull, G. Gradwohl, and P. Gruss. 2003. Opposing actions of Arx and Pax4 in endocrine pancreas development. Genes Dev. 17(20): 2591-2603.

[51] Sosa-Pineda, B., K. Chowdhury, M. Torres, G. Oliver, and P. Gruss. 1997. The Pax4 gene is essential for differentiation of insulin-producing beta cells in the mammalian pancreas. Nature, 386(6623): 399-402.

[52] Itkin-Ansari, P., E. Marcora, I. Geron, B. Tyrberg, C. Demeterco, E. Hao, C. Padilla, C. Ratineau, A. Leiter, J. E. Lee, and F. Levine. 2005. NeuroD1 in the endocrine pancreas: localization and dual function as an activator and repressor. Dev. Dyn. 233(3): 946-953.

[53] Sussel, L., J. Kalamaras, D. J. Hartigan-O'Connor, J. J. Meneses, R. A. Pedersen, J. L. Rubenstein, and M. S. German. 1998. Mice lacking the homeodomain transcription factor $\mathrm{Nkx} 2.2$ have diabetes due to arrested differentiation of pancreatic beta cells. Development, 125(12): 2213-2221.

[54] Sander, M., L. Sussel, J. Conners, D. Scheel, J. Kalamaras, F. Dela Cruz, V. Schwitzgebel, A. Hayes-Jordan, and M. German. 2000. Homeobox gene Nkx6.1 lies downstream of Nkx2.2 in the major pathway of betacell formation in the pancreas. Development, 127(24): 5533-5540.

[55] Henseleit, K. D., S. B. Nelson, K. Kuhlbrodt, J. C. Hennings, J. Ericson, and M. Sander. NKX6 transcription factor activity is required for alphaand beta-cell development in the pancreas. Development, 132(13): 3139-49.

[56] Collombat, P., J. Hecksher-Sorensen, V. Broccoli, J. Krull, I. Ponte, T. Mundiger, J. Smith, P. Gruss, P. Serup, and A. Mansouri. 2005. The simultaneous loss of Arx and Pax 4 genes promotes a somatostatinproducing cell fate specification at the expense of the alpha- and beta-cell lineages in the mouse endocrine pancreas. Development, 132(13): 2969-2980.

[57] St-Onge, L., B. Sosa-Pineda, K. Chowdhury, A. Mansouri, and P. Gruss. Pax6 is required for differentiation of glucagon-producing alpha-cells in mouse pancreas. Nature, 387(6631): 406-409.

[58] Dohrmann, C., P. Gruss, and L. Lemaire. 2000. Pax genes and the differentiation of hormone-producing endocrine cells in the pancreas. Mech. Dev. 92(1): 47-54. 
[59] Artner, I., Y. Hang, M. Mazur, T. Yamamoto, M. Guo, J. Lindner, M. A. Magnuson, and R. Stein. 2010. MafA and MafB regulate genes critical to beta-cells in a unique temporal manner. Diabetes, 59(10): 2530-2539.

[60] Nishimura, W., T. Kondo, T. Salameh, I. El Khattabi, R. Dodge, S. Bonner-Weir, and A. Sharma. 2006. A switch from MafB to MafA expression accompanies differentiation to pancreatic beta-cells. Dev. Biol. 293(2): 526-539.

[61] Zhang, C., T. Moriguchi, M. Kajihara, R. Esaki, A. Harada, H. Shimohata, H. Oishi, M. Hamada, N. Morito, K. Hasegawa, T. Kudo, J. D. Engel, M. Yamamoto, and S. Takahashi. 2005. MafA is a key regulator of glucose-stimulated insulin secretion. Mol. Cell Biol. 25(12): 4969-4976.

[62] Artner, I., J. Le Lay, Y. Hang, L. Elghazi, J. C. Schisler, E. Henderson, B. Sosa-Pineda, and R. Stein. MafB: an activator of the glucagon gene expressed in developing islet alpha- and beta-cells. Diabetes, 55(2): 297-304.

[63] Mastracci, T. L., K. R. Anderson, J. B. Papizan, and L. Sussel. 2013. Regulation of Neurod1 contributes to the lineage potential of Neurogenin3+ endocrine precursor cells in the pancreas. PLoS Genet. 9(2): e1003278.

[64] Brolen, G. K., N. Heins, J. Edsbagge, and H. Semb. 2005. Signals from the embryonic mouse pancreas induce differentiation of human embryonic stem cells into insulin-producing beta-cell-like cells. Diabetes, 54(10): 2867-2874.

[65] D'Amour, K. A., A. D. Agulnick, S. Eliazer, O. G. Kelly, E. Kroon, and E. E. Baetge. Efficient differentiation of human embryonic stem cells to definitive endoderm. Nat. Biotechnol. 23(12): 1534-1541.

[66] D’Amour, K. A., A. G. Bang, S. Eliazer, O. G. Kelly, A. D. Agulnick, N. G. Smart, M. A. Moorman, E. Kroon, M. K. Carpenter, and E. E. Baetge. 2006. Production of pancreatic hormone-expressing endocrine cells from human embryonic stem cells. Nat. Biotechnol. 24(11): 1392-1401.

[67] Kroon, E., L. A. Martinson, K. Kadoya, A. G. Bang, O. G. Kelly, S. Eliazer, H. Young, M. Richardson, N. G. Smart, J. Cunningham, A. D. Agulnick, K. A. D' Amour, M. K. Carpenter, and E. E. Baetge. 2008. Pancreatic endoderm derived from human embryonic stem cells generates glucose-responsive insulin-secreting cells in vivo. Nat. Biotechnol. 26(4): 443-452. 
[68] Zhang, D., W. Jiang, M. Liu, X. Sui, X. Yin, S. Chen, Y. Shi, and H. Deng. Highly efficient differentiation of human ES cells and iPS cells into mature pancreatic insulin-producing cells. Cell Res. 19(4): 429-438.

[69] Huang, P., Z. He, S. Ji, H. Sun, D. Xiang, C. Liu, Y. Hu, X. Wang, and L. Hui. 2011. Induction of functional hepatocyte-like cells from mouse fibroblasts by defined factors. Nature, 475(7356): 386-389.

[70] Sapir, T., K. Shternhall, I. Meivar-Levy, T. Blumenfeld, H. Cohen, E. Skutelsky, S. Eventov-Friedman, I. Barshack, I. Goldberg, S. Pri-Chen, L. Ben-Dor, S. Polak-Charcon, A. Karasik, I. Shimon, E. Mor, and S. Ferber. 2005. Cell-replacement therapy for diabetes: Generating functional insulin-producing tissue from adult human liver cells. Proc. Natl. Acad. Sci. USA, 102(22): 7964-7969.

[71] Zaret, K. S., and M. Grompe. 2008. Generation and regeneration of cells of the liver and pancreas. Science, 322(5907): 1490-1494.

[72] Chung, C. H., E. Hao, R. Piran, E. Keinan, and F. Levine 2010. Pancreatic beta-cell neogenesis by direct conversion from mature alpha-cells. Stem Cells, 28(9): 1630-1638.

[73] Thorel, F., and P. L. Herrera. 2010. Conversion of adult pancreatic alphacells to beta-cells in diabetic mice. Med. Sci. (Paris) 26(11): 906-909.

[74] Collombat, P., X. Xu, P. Ravassard, B. Sosa-Pineda, S. Dussaud, N. Billestrup, O. D. Madsen, P. Serup, H. Heimberg, and A. Mansouri. 2009. The ectopic expression of Pax4 in the mouse pancreas converts progenitor cells into alpha and subsequently beta cells. Cell, 138(3): 449-462.

[75] Ball, G. D., M. J. Weigensberg, M. L. Cruz, G. Q. Shaibi, H. A. Kobaissi, and M. I. Goran. 2005. Insulin sensitivity, insulin secretion and beta-cell function during puberty in overweight Hispanic children with a family history of type 2 diabetes. Int. J. Obes. (Lond) 29(12): 1471-1477.

[76] Newsholme, P., V. Cruzat, F. Arfuso, and K. Keane. 2014. Nutrient regulation of insulin secretion and action. J. Endocrinol. 221(3): R105-R120.

[77] Rhodes, C. J., and M. F. White. 2002. Molecular insights into insulin action and secretion. Eur. J. Clin. Invest. 32(3): 3-13.

[78] Wiederkehr, A., and C. B. Wollheim. 2006. Minireview: implication of mitochondria in insulin secretion and action. Endocrinology, 147(6): 2643-9. 
[79] Jacobson, D. A., and L. H. Philipson. 2007. Action potentials and insulin secretion: new insights into the role of Kv channels. Diabetes. Obes. Metab. 9(2): 89-98.

[80] Miyazaki, Y., H. Akasaka, H. Ohnishi, S. Saitoh, R. A. DeFronzo, and K. Shimamoto. 2008. Differences in insulin action and secretion, plasma lipids and blood pressure levels between impaired fasting glucose and impaired glucose tolerance in Japanese subjects. Hypertens. Res. 31(7): 1357-1363.

[81] Koster, J. C., M. A. Permutt, and C. G. Nichols. 2005. Diabetes and insulin secretion: the ATP-sensitive K+ channel (K ATP) connection. Diabetes, 54(11): 3065-3072.

[82] Martin-Gronert, M. S. and S. E. Ozanne. 2012. Metabolic programming of insulin action and secretion. Diabetes Obes. Metab, 14(3): 29-39.

[83] Ambros, V. 2004. The functions of animal microRNAs. Nature, 431(7006): 350-355.

[84] Joglekar, M. V., V. S. Parekh, and A. A. Hardikar. 2011. Islet-specific microRNAs in pancreas development, regeneration and diabetes. Indian J. Exp. Biol, 49(6): 401-408.

[85] Joglekar, M. V., V. M. Joglekar, and A. A. Hardikar. 2009. Expression of islet-specific microRNAs during human pancreatic development. Gene. Expr. Patterns, 9(2): 109-113.

[86] Xia, H. Q., Y. Pan, J. Peng, and G. X. Lu. 2011. Over-expression of miR375 reduces glucose-induced insulin secretion in Nit-1 cells. Mol. Biol. Rep. 38(5): 3061-3065.

[87] Poy, M. N., L. Eliasson, J. Krutzfeldt, S. Kuwajima, X. Ma, P. E. Macdonald, S. Pfeffer, T. Tuschl, N. Rajewsky, P. Rorsman, and M. Stoffel. 2004. A pancreatic islet-specific microRNA regulates insulin secretion. Nature, 432(7014): 226-230.

[88] Pullen, T. J., G. da Silva Xavier, G. Kelsey, and G. A. Rutter. 2011. miR29a and miR-29b contribute to pancreatic beta-cell-specific silencing of monocarboxylate transporter 1 (Mct1). Mol. Cell. Biol. 31(15): 3182-3194.

[89] Baroukh, N., M. A. Ravier, M. K. Loder, E. V. Hill, A. Bounacer, R. Scharfmann, G. A. Rutter, and E. Van Obberghen. 2007. MicroRNA124a regulates Foxa2 expression and intracellular signaling in pancreatic beta-cell lines. J. Biol. Chem. 282(27): 19575-19588.

[90] Roggli, E., A. Britan, S. Gattesco, N. Lin-Marq, A. Abderrahmani, P. Meda, and R. Regazzi. 2010. Involvement of microRNAs in the 
cytotoxic effects exerted by proinflammatory cytokines on pancreatic beta-cells. Diabetes, 59(4): 978-986.

[91] Lovis, P., E. Roggli, D. R. Laybutt, S. Gattesco, J. Y. Yang, C. Widmann, A. Abderrahmani, and R. Regazzi. 2008. Alterations in microRNA expression contribute to fatty acid-induced pancreatic beta-cell dysfunction. Diabetes, 57(10): 2728-2736.

[92] Zhang, Z. W., T. Men, R. C. Feng, Y. C. Li, D. Zhou, and C. B. Teng. 2013. miR-375 inhibits proliferation of mouse pancreatic progenitor cells by targeting YAP1. Cell Physiol. Biochem. 32: 1808-1817.

[93] Yang, Y., L. Ding, Y. An, Z. W. Zhang, Y. Lang, S. Tai, F. Guo, and C. B. Teng. 2012. MiR-18a regulates expression of the pancreatic transcription factor Ptf 1 a in pancreatic progenitor and acinar cells. FEBS Lett. 586(4): 422-427.

[94] Zhang, Z. W., L. Q. Zhang, L. Ding, F. Wang, Y. J. Sun, Y. An, Y. Zhao, Y. H. Li, and C. B. Teng. 2011. MicroRNA-19b downregulates insulin 1 through targeting transcription factor NeuroD1. FEBS Lett. 585(16): 2592-2598.

[95] Upchurch, S. L. 2007. Review: lifestyle or pharmacological interventions prevent or delay type 2 diabetes in people with impaired glucose tolerance. Evid. Based Nurs. 10(3): 78.

[96] Olokoba, A. B., O. A. Obateru, and L. B. Olokoba. 2012. Type 2 diabetes mellitus: a review of current trends. Oman Med. J. 27(4): 269-273.

[97] Moore, F., M. L. Colli, M. Cnop, M. I. Esteve, A. K. Cardozo, D. A. Cunha, M. Bugliani, P. Marchetti, and D. L. Eizirik. 2009. PTPN2, a candidate gene for type 1 diabetes, modulates interferon-gammainduced pancreatic beta-cell apoptosis. Diabetes, 58(6): 1283-1291.

[98] Barthson, J., C. M. Germano, F. Moore, A. Maida, D. J. Drucker, P. Marchetti, C. Gysemans, C. Mathieu, G. Nunez, A. Jurisicova, D. L. Eizirik, and E. N. Gurzov. 2011. Cytokines tumor necrosis factor-alpha and interferon-gamma induce pancreatic beta-cell apoptosis through STAT1-mediated Bim protein activation. J. Biol. Chem. 286(45): 39632-39643.

[99] Matsuda, T., K. Ferreri, I. Todorov, Y. Kuroda, C. V. Smith, F. Kandeel, and Y. Mullen. 2005. Silymarin protects pancreatic betacells against cytokine-mediated toxicity: implication of c-Jun NH2terminal kinase and janus kinase/signal transducer and activator of transcription pathways. Endocrinology, 146(1): 175-185.

[100] El-Assaad, W., J. Buteau, M. L. Peyot, C. Nolan, R. Roduit, S. Hardy, E. Joly, G. Dbaibo, L. Rosenberg, and M. Prentki. 2003. Saturated fatty 
acids synergize with elevated glucose to cause pancreatic beta-cell death. Endocrinology, 144(9): 4154-4163.

[101] Annes, J. P., J. H. Ryu, K. Lam, P. J. Carolan, K. Utz, J. Hollister-Lock, A. C. Arvanites, L. L. Rubin, G. Weir, and D. A. Melton. 2012. Adenosine kinase inhibition selectively promotes rodent and porcine islet beta-cell replication. Proc. Natl. Acad. Sci. USA, 109(10): 3915-3920.

[102] Watanabe, T., Y. Yonemura, H. Yonekura, Y. Suzuki, H. Miyashita, K. Sugiyama, S. Moriizumi, M. Unno, O. Tanaka, H. Kondo, et al. 1994. Pancreatic beta-cell replication and amelioration of surgical diabetes by Reg protein. Proc. Natl. Acad. Sci. USA, 91(9): 3589-3592.

[103] Garber, A. J. 2011. Incretin effects on beta-cell function, replication, and mass: the human perspective. Diabetes Care, 34(2): S258-S263.

[104] Bouwens, L., and I. Rooman. 2005. Regulation of pancreatic beta-cell mass. Physiol. Rev. 85(4): 1255-1270.

[105] Bonner-Weir, S. 1994. Regulation of pancreatic beta-cell mass in vivo. Recent Prog. Horm. Res. 49: 91-104.

[106] Cai, Q., P. Bonfanti, R. Sambathkumar, K. Vanuytsel, J. Vanhove, C. Gysemans, M. Debiec-Rychter, S. Raitano, H. Heimberg, L. Ordovas, and C. M. Verfaillie. 2014. Prospectively isolated NGN3-expressing progenitors from human embryonic stem cells give rise to pancreatic endocrine cells. Stem Cells Transl. Med. 3(4): 489-499.

[107] Li, W. C., J. M. Rukstalis, W. Nishimura, V. Tchipashvili, J. F. Habener, A. Sharma, and S. Bonner-Weir. 2010. Activation of pancreatic-ductderived progenitor cells during pancreas regeneration in adult rats. J. Cell Sci. 123(Pt 16): 2792-2802.

[108] Hess, D., L. Li, M. Martin, S. Sakano, D. Hill, B. Strutt, S. Thyssen, D. A. Gray, and M. Bhatia. 2003. Bone marrow-derived stem cells initiate pancreatic regeneration. Nat. Biotechnol. 21(7): 763-770.

[109] Cloutier, F., M. M. Siegenthaler, G. Nistor, and H. S. Keirstead. 2006. Transplantation of human embryonic stem cell-derived oligodendrocyte progenitors into rat spinal cord injuries does not cause harm. Regen. Med. 1(4): 469-479.

[110] Tateishi, K., J. He, O. Taranova, G. Liang, A. C. D'Alessio, and Y. Zhang. 2008. Generation of insulin-secreting islet-like clusters from human skin fibroblasts. J. Biol. Chem. 283(46): 31601-31607.

[111] Hou, P., Y. Li, X. Zhang, C. Liu, J. Guan, H. Li, T. Zhao, J. Ye, W. Yang, K. Liu, J. Ge, J. Xu, Q. Zhang, Y. Zhao, and H. Deng. 2013. Pluripotent stem cells induced from mouse somatic cells by small-molecule compounds. Science, 341(6146): 651-654. 
[112] Shiraki, N., T. Yoshida, K. Araki, A. Umezawa, Y. Higuchi, H. Goto, K. Kume, and S. Kume. 2008. Guided differentiation of embryonic stem cells into Pdx1-expressing regional-specific definitive endoderm. Stem Cells, 26(4): 874-885.

[113] Chen, S., M. Borowiak, J. L. Fox, R. Maehr, K. Osafune, L. Davidow, K. Lam, L. F. Peng, S. L. Schreiber, L. L. Rubin, and D. Melton. 2009. A small molecule that directs differentiation of human ESCs into the pancreatic lineage. Nat. Chem. Biol. 5(4): 258-265.

[114] Yuan, Y., K. Hartland, Z. Boskovic, Y. Wang, D. Walpita, P. A. Lysy, C. Zhong, D. W. Young, Y. K. Kim, N. J. Tolliday, E. M. Sokal, S. L. Schreiber, and B. K. Wagner. 2013. A small-molecule inducer of PDX1 expression identified by high-throughput screening. Chem. Biol. 20(12) 1513-1522.

[115] Dadheech, N., S. Soni, A. Srivastava, S. Dadheech, S. Gupta, R. Gopurappilly, and R. R. Bhonde. 2013. A Small Molecule Swertisin from Enicostemma littorale Differentiates NIH3T3 Cells into Islet-Like Clusters and Restores Normoglycemia upon Transplantation in Diabetic Balb/c Mice. Evid. Based. Complement. Alternat. Med. 2013: 280392.

[116] Shen, W., M. S. Tremblay, V. A. Deshmukh, W. Wang, C. M. Filippi, G. Harb, Y. Q. Zhang, A. Kamireddy, J. E. Baaten, Q. Jin, T. Wu, J. G. Swoboda, C. Y. Cho, J. Li, B. A. Laffitte, P. McNamara, R. Glynne, X. Wu, A. E. Herman, and P. G. Schultz. 2013. Small-molecule inducer of beta cell proliferation identified by high-throughput screening. J. Am. Chem. Soc. 135(5): 1669-1672.

[117] Liu, J., Y. Liu, H. Wang, H. Hao, Q. Han, J. Shen, J. Shi, C. Li, Y. Mu, and W. Han. 2013. Direct differentiation of hepatic stem-like WB cells into insulin-producing cells using small molecules. Sci. Rep. 3: 1185.

[118] Matsumoto, S., H. Noguchi, Y. Yonekawa, T. Okitsu, Y. Iwanaga, X. Liu, H. Nagata, N. Kobayashi, and C. Ricordi. 2006. Pancreatic islet transplantation for treating diabetes. Expert Opin. Biol. Ther. 6(1): 23-37.

[119] Nouha, B.O., Monica, C., Andhira, V., Anja, P., Noemie, D., Elisabet, G., Bijana, F., Fabio, A., Patrick, C. 2013. From pancreatic islet formation to beta-cell regeneration. Diabetes Res. Clin. Pr. 101(1): 1-9.

[120] Shah, A. P., R. S. Mangus, J. A. Powelson, K. P. Samy, T. E. Taber, M. L. Goble, and J. A. Fridell. 2013. Impact of recipient age on whole organ pancreas transplantation. Clin. Transplant. 27(1): E49-E55. 


\section{Biography}

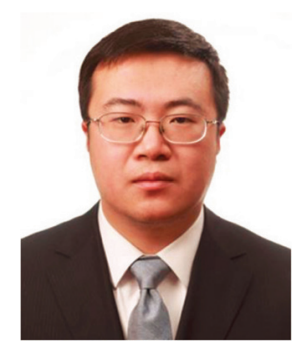

Y. Zhao is a lecturer of Biology at the Northeast University, China. He received his Ph.D. from Jilin University, and eventually earned a joint training degree from Peking University. After his five-year career as postgraduate on transgenic animals and murine stem cell projects, Dr. Yicheng decided it was time for a change of research area and moved to Harbin, a beautiful city in North China, where he was offered tenure at Northeast Forestry University. In addition to teaching, Dr. Yicheng is focusing on non-coding RNA and pancreatic precursor/stem cell. 
